\title{
Infrastructure projects as a value co-creation process
}

\author{
Giuseppe Cappiello, Paola Garrone, Paolo Nardi
}

\section{Introduction}

In recent years public service's companies, citizens and policymakers expressed concern regarding the realization of infrastructure projects. Infrastructures are fundamental for public service provisioning therefore the demand for reliable, diffuse, and environment-friendly arrangements is growing at a significant rate worldwide, above all those related with information and communication technology, whereas the planning-to-delivery process continues to meet certain difficulties.

Although the most complications emerge during the building or operation phases, many cases of conflict, inefficiency, or poor quality have roots that go back to failures in the early stages.

The public utility is the depositary of the technical knowledge and the necessary competence for ordinary and extraordinary maintenance but many actors are involved with utility firms in infrastructure development since the initial phase of the project, e.g. local governments, other administrations, citizens, landowners, environmental advocacy groups so we decided to explore this theme in a co-creation perspective.

We mean the value co-creation process as a collaborative practice employed by firms and other stakeholders finalised to obtain a result, to reach a solution therefore to create value, in our case the early stage of an infrastructure project.

This work aims to add to the research about utility management and public interest services the understanding about the conduit through which collaborative initiatives can support the planning, high-level design, and siting of local infrastructures project. We are interested to explore along which route the collaboration could be useful and benefit could be gained from a collaborative behaviour.

As a result, we propose a model where knowledge exchange, time and cost efficiency and public acceptance are involved in the project management and therefore in the value co-creation.

The relevance of the model has been empirically analysed in the sector of Italian utilities. A survey has been addressed to informed and experienced managers of environment and local transport utilities.

The work is organized as follows. Section 1 describes the early stage of infrastructure projects. Section 2 summarizes existing literature, and discusses the conceptual model. Data and methods are introduced in Section 3, results in Section 4. The conclusions are presented in Section 5.

\section{The early project stages}

Governments, administrations, for-profit firms and non-profit organizations need to work together to the extent that a public goal, a solution, cannot be achieved easily by individual organizations operating independently (Provan and Kenis, 2008). This is particularly true in infrastructure projects.

The local infrastructure consists of gas and district heating pipelines, electricity distribution grids, water pipes and sewers, wastewater treatment plants, public transport networks and projects (e.g. roads, railways, undergrounds, tramways, airports), waste collection and treatment facilities and communications networks.

Figure 1 frames the early project activities within the infrastructure life cycle. Planning by local or national governments typically moves from the recognition of users' needs to the ideation of a new project and the adoption and prioritization of an investment plan. The high-level design of the facility is carried out mainly by the utility firms (or facility developer). Activities include an accurate demand analysis, the development of options, time plans, cost analyses, environmental assessments, and capital budgeting. A preliminary selection of technologies and project engineering are completed in the building phase. Last of all, choosing a location, negotiating with residents and landowners to open the site, obtaining permits and rights of way, and interconnecting with other utilities make up the siting phase. Depending on sector regulations, the process owner may be the utility or local 
government. The process is far from being sequential (Furlong et al. 2016). For example, project concept and timing revisions are frequent, while activities, such as obtaining feedback regarding options and cost analysis can be lengthy and complicated.

Figure 1-Early project activities in the project life cycle

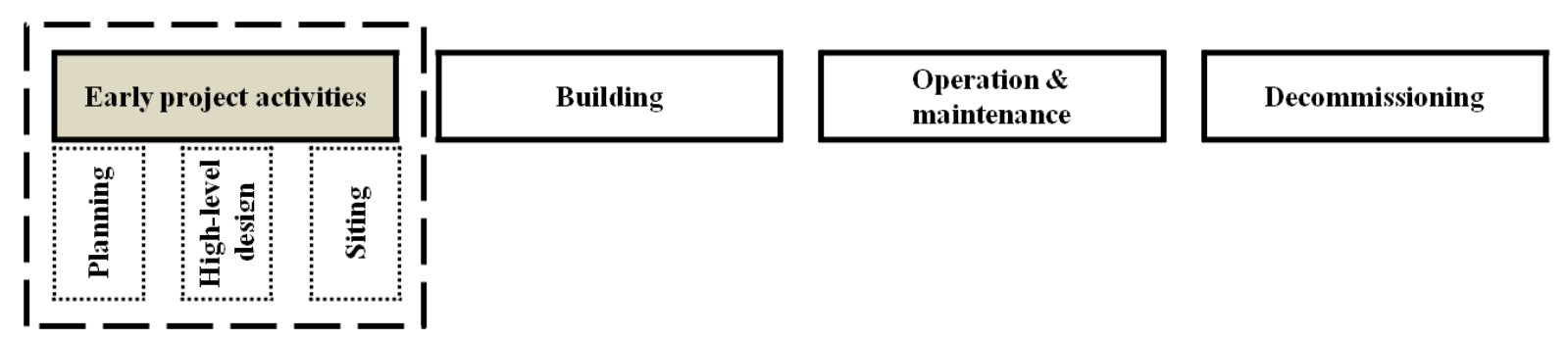

All the project activities undertaken before beginning construction rely on the technical and organizational competences of public planners or utility companies. At the same time, they demand a large and differentiated set of material and immaterial resources, e.g. rights-of-way, information about potential demand, a good command of alternative technology, cartographic documentation, permits, and the ongoing plans of other utilities and administrations, which are controlled by a network of administrations, enterprises, individual citizens and non-profit associations (Ostrom et al. 1993). As a result, the structure of infrastructure agreement is truly multilateral, as it encompasses numerous and heterogeneous players. Table 1 provides an overview of early activities and the actors involved.

Scholars from different persuasions have argued against the traditional dichotomy between hierarchical governance and extensive outsourcing to the private sector, and have put forward instead, the hypothesis that some degree of collaboration between governments, utilities, citizens and other involved players is necessary (e.g. Ostrom et al. 1993; Koppenjan 2005; Hefetz and Warner 2007, Gnan et al, 2013).

Before entering the most relevant theories and analyses from a broad range of literature, it is worth focusing on the types obstacles that arise in early project phases: little or uncertain knowledge of user needs and geographic and environmental characteristics, unpredictable timelines, particularly in terms of authorization and permit acquisition, the mobilization of residents or interest groups in conflict with the development.

In particular, we found three aspects that may compromise the result and the value creation:

Knowledge exchange and learning. Ostrom et al. (1993) have beautifully made the point that infrastructures are time- and place-specific goods, which cannot be generalized. If local governments and utilities only rely on scientific and technical codified knowledge, they will inevitably have trouble understanding the key project elements and end up creating "marvels that languish underutilized". A wide and differentiated set of information, which is partly embodied in the tacit know-how of other parties, is required not only to develop project options that are suitable for the territory in question, but also to estimate demand (Marvin and Guy 1997). Classical planning suffers from organizational fragmentation, which implies a weak decision-making process and the formulation of solutions that are suboptimal, while successful interactive planning experiences have introduced interaction and learning processes that facilitate mutual understanding and improve project quality (Glasbergen and Driessen 2005). A steady and voluntary collaboration between heterogeneous actors has the potential to generate formal and informal knowledge flows and favour learning processes (Hillier 2000). However, the need of some degree of cognitive proximity between participants leads to a trade-off in the learning-by-interaction process if participants are highly heterogeneous (Nooteboom 2000). 
Table 1 - Early activities in infrastructure projects and the actors involved

\begin{tabular}{|c|c|c|c|c|c|c|c|c|c|}
\hline & \multicolumn{9}{|c|}{ Actors $^{\circ}$} \\
\hline Activity & $\begin{array}{c}\text { Local } \\
\text { government }\end{array}$ & Utility & $\begin{array}{l}\text { Citizens } \\
\text { and } \\
\text { landowners }\end{array}$ & $\begin{array}{l}\text { Environmental } \\
\text { and heritage } \\
\text { associations }\end{array}$ & $\begin{array}{c}\text { User } \\
\text { associations }\end{array}$ & Suppliers & $\begin{array}{l}\text { Financial } \\
\text { institutions }\end{array}$ & $\begin{array}{c}\text { Other } \\
\text { authorities* }\end{array}$ & $\begin{array}{l}\text { Other } \\
\text { utilities }\end{array}$ \\
\hline Planning & & & & & & & & & \\
\hline $\begin{array}{l}\text { Needs assessment, } \\
\text { Project concept, Plan } \\
\text { adoption and } \\
\text { prioritization }\end{array}$ & & & & & & & & & \\
\hline High-level design & & & & & & & & & \\
\hline $\begin{array}{l}\text { Demand analysis, } \\
\text { Development of options, } \\
\text { Preliminary technology } \\
\text { selection and } \\
\text { engineering, Timing, } \\
\text { Cost analysis, } \\
\text { Environmental } \\
\text { assessment and } \\
\text { authorization, Capital } \\
\text { budgeting }\end{array}$ & & & & & & & & & \\
\hline Siting & & & & & & & & & \\
\hline $\begin{array}{l}\text { Location choice, } \\
\text { Permitting, Negotiation } \\
\text { with land owners and } \\
\text { neighboring } \\
\text { communities, } \\
\text { Interconnection } \\
\text { agreements }\end{array}$ & & & & & & & & & \\
\hline
\end{tabular}

Source: Own elaboration

Notes. ${ }^{\circ}$ Black cells, $[$ : process owner; Grey cells, : involved players. *Other authorities: national or regional governments; other local governments; sector, environment, health and safety authorities. 

Time and cost efficiency. Planning, high-level design and siting activities frequently suffer from time and cost overruns and a new planning framework could be considered (Furlong et al, 2016). There are many reasons why projects are slowed down and costs escalate. Regulations proliferate and impose time-consuming procedures ("red-tape", Glasbergen and Driessen 2005). Negotiation procedures between parties are far from being standardized (Marvin and Guy 1997). The implementation of policy decisions cannot be taken for granted due to an inadequate definition of problems and solutions, and also because of divergent objectives and interests (Ennis 2003, Marvin and Guy 1997). In addition to unintentional errors, costs and times can be strategically underrepresented in order to obtain project approval or to make pressure on the management and staff (Flyvbjerg et al. 2002). The lack of appropriate checks and balances could, in turn cause a deception (Flyvbjerg 2009). Whereas, engaging the public from the very beginning of the project allows necessary changes to be identified and implemented quickly and cheaply (Cotton and Devin-Wright 2011). Various forms of stakeholders' engagement are expected to reinforce the governance of infrastructure projects (Glasbergen and Driessen 2005), and strengthen social capital, which in turn could reduce the event of opportunism (Nooteboom 2000).

Public acceptance. Most infrastructures are unpopular at a local level. Residents are likely to express opposition to the development of large-scale projects, particularly if they incur health or environment costs. This problem may be magnified by misperceptions of risk (i.e. by a lack of knowledge about the project), underestimation of benefits or by the ex-ante propensity of certain neighbourhoods to engage in collective action (Garrone and Groppi, 2012). Engaging stakeholders should therefore involve managing a wide divergence of expectation while providing the best possible facilities (Beach et al. 2012). Consulting and involving the public can create a basis for support (Glasbergen and Driessen 2005, Schweizer and Bovet, 2016). By fostering informed participation in public and local associations, collaborative initiatives can reduce the information barriers between industry and the public, avoid risk misperception, and promote agreement.

\section{Literature review and conceptual framework}

In order to identify the way to remove or reduce the impact of these obstacles that emerge in the project management and explain why and how different actor should collaborate in the early stage of an infrastructure project, we adopted the value co-creation framework, namely we would like to understand how value is created through the collaboration and the interaction between participants to the process of project realization.

Collaboration is a" long-term relationship and is characterized by high level of interdependency" Keast, Mandell (2014). Collaboration if a kind of working together different form cooperation and coordination because it is not a shot-term strategy or a way to achieve a predefined objective (id.)

Certain cases are a practical illustration of the nature of collaboration in the early stages of infrastructure projects. The following examples display different patterns, even though all of them are targeted at the development of infrastructural facilities. An initial distinction can be made between initiatives driven by legal obligations, i.e. Authorization Commissions, and initiatives undertaken voluntarily. Particular attention will be given to the latter, as they give a clearer picture of the impact and characteristics of these cooperative agreements.

- $\quad$ Regulated Committees. These are initiated by authorities to address planning and siting issues. Their main purpose is to improve project efficiency by streamlining processes and avoiding cost and time escalation, but they also stimulate the exchange of fresh knowledge on issues that are crucial for public acceptance and project quality, such as user needs, safety and environmental impact, and other intervening projects. Like the Authorization Commissions, they involve formalized decision-making procedures and issue regulatory obligations. A clear example is the Italian "service committee" (Governa and Salone 2005).

Bottom-up Agreements. These are networks that can also be initiated by utilities. They are generally multi-purpose (e.g. public acceptance, knowledge exchange and learning, process efficiency), and focus on siting and high-level design activities. Binding decisions are enforced 
through private agreements. An example of a "bottom-up agreement" in the urban waste management sector is offered by Hera, a large Italian utility (with sales of 8 billion Euros in 2015). When developing waste treatment plants in response to regional planning, Hera uses cooperative agreements with local governments and neighbourhood committees.

Public Engagement and Participation. Participatory practices are a special instance of publicprivate interaction. The focus on early project phases makes them a relevant case for our purposes, even though organizational links are generally quite loose, and local governments interact mainly with the public and citizens' representatives. Various instruments can be adopted to engage citizenship, such as public hearings, interviews, web forums, focus groups (Dürrenberger et al. 1999), town meetings (Sclove 2000), and participatory inquiries (Fischer 1999). Deliberative practices include citizens' panels or juries and referenda (Hörning 1999). (Schweizer and Bovet 2016).

- Community Asset Ownership. A final class lies on the border between early project stages and subsequent building and operating phases. The community, having taken part into the concept and adoption of a plan, and in some cases the high-level design and siting of infrastructure projects too, is also then involved in asset ownership and management. Many of these cases concern renewable energy facilities, such as the community wind farms spread across the UK, Germany, the USA, New Zealand and Australia (Walker and Devine-Wright 2008), or community micro-generation facilities (Watson 2004). Table 2 summarizes the main elements of the collaborative initiatives mentioned so far. The examples help to establish the concept of collaborative approach as described in this paper: multilateral initiatives that focus on the development and adoption of infrastructure policies.

Table 2 -Collaboration in early project activities: a classification

\begin{tabular}{|c|c|c|c|c|}
\hline & Activities & Main objectives & Process & Leadership \\
\hline $\begin{array}{r}\text { Regulated } \\
\text { Committeees }\end{array}$ & $\begin{array}{l}\text { Planning, } \\
\text { Siting }\end{array}$ & $\begin{array}{l}\text { Time and cost efficiency, } \\
\text { Public acceptance }\end{array}$ & Regulated & Government \\
\hline $\begin{array}{l}\text { Bottom-up } \\
\text { agreements }\end{array}$ & $\begin{array}{l}\text { Siting, } \\
\text { High-level } \\
\text { design }\end{array}$ & $\begin{array}{l}\text { Knowledge exchange and } \\
\text { learning, Time and cost } \\
\text { efficiency, Public acceptance }\end{array}$ & Negotiated & Utility \\
\hline $\begin{array}{c}\text { Public } \\
\text { participation }\end{array}$ & $\begin{array}{l}\text { Planning, } \\
\text { Siting }\end{array}$ & $\begin{array}{c}\text { Public acceptance, } \\
\text { Knowledge exchange and } \\
\text { learning }\end{array}$ & $\begin{array}{l}\text { Regulated } \\
\text { / Negotiated }\end{array}$ & Government \\
\hline $\begin{array}{l}\quad \text { Community } \\
\text { asset } \\
\text { ownership }^{\circ}\end{array}$ & $\begin{array}{c}\text { Planning, } \\
\text { High-level } \\
\text { design, Siting }\end{array}$ & $\begin{array}{l}\text { Knowledge exchange and } \\
\text { learning, Financing }\end{array}$ & Negotiated & $\begin{array}{l}\text { Citizens } \\
\text { committees }\end{array}$ \\
\hline
\end{tabular}

Source: Own elaboration

Note: Community Asset Ownership also extends to infrastructure financing, construction and operation.

The literature about value co-creation could shed light and add another perspective on this dynamic. Although the prevalence of studies related to co-creation dealing with the dyadic relationship between supplier and customer there are also some contributions on the collaborative network. Jaakkola and Hakanen (2013) for example investigated value perception when the supplier is a solution network ${ }^{1}$ that integrate resource to save time and cost. Mele (2011) faces the issue of project network, a structured relationship made up to run a project, and the effect of conflicts that arise during the project execution on the value creation.

Value co-creation gained a growing attention in recent years and has two main elements that characterize the concept: co-production and value in use (Ranjan, Read, 2016). Co-production is the join participation in the production process while value in use includes learning by the participants in the interaction phase.

In providing public services, the creation of value is a consequence of the continuous search of

\footnotetext{
${ }^{1}$ An integrated solution is a "bundle of products and/or services that meet customer specific needs" Jaakkola and Hakanen
} (2013) 
consonance with other systems like citizens, communities, local authorities, other companies (Golinelli, 2000; Miglietta, 2005).

A few existing studies have already examined types of public-private interaction that are close to the collaborative approach analysed by this paper. Koppenjan (2005) defines "PPP in the planning phase" as an institutional arrangement that "deals with structured cooperation aimed at the development of a project" in the exploratory and planning phases, i.e. it is aimed at project ideation, definition and design. Glasbergen and Driessen (2005) analyse the case of interactive planning in the Netherlands, and emphasise that interactive planning aims at developing and implementing a project by focusing public and private party interaction on it, facilitating that interaction and linking it to the formal decision-making process. This entails various legal forms of "structured collaboration" and binding agreements.

A co-creation approach to the early stages of urban infrastructure projects is quite far from publicprivate partnerships (PPPs). PPPs cover the building or operating stages. In order to build an effective risk-sharing relationship, they establish joint ventures or long-term contracts between public and private partners. Nevertheless, they generally exclude close organizational links between partners (Hodge and Greve 2007, Kwak et al. 2009). Instead, co-creation via collaboration demands structured and repeated interaction in order to cope with the challenges of infrastructure planning, design and siting (Koppenjan 2005, Glasbergen and Driessen 2005, Beach et al. 2012). Moreover, bilateral public-private relations dominate PPPs, whereas multiple and heterogeneous players participate in planning networks. Collaborative approaches to early project stages only in part overlap with public engagement practices and issue networks that are centred on loose organizational links between local government and citizens (see, among others, Hillier 2000, Cooper et al. 2006, Hefetz and Warner 2007, Groves et al. 2013; Hodge and Greve 2007; Wiewiora et al. 2016).

The conceptual model illustrated in Figure 2 summarizes the vision that we have now developed of the collaborative approach, its main benefits and costs, and the moderating role-played by its structure and organization and by the context.

Figure 2 - Collaborative approaches (CLAIP) to early project stages: conceptual model

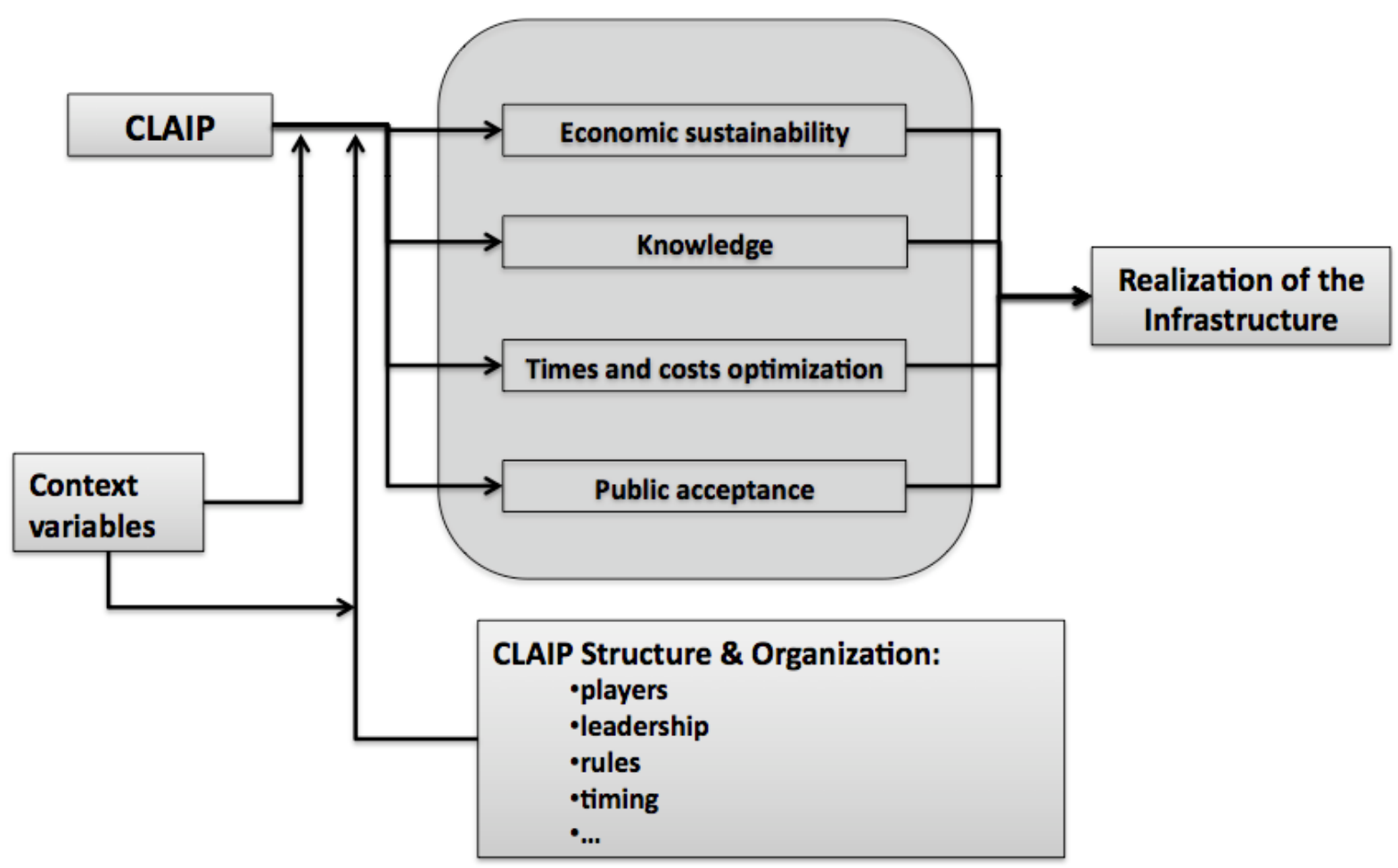

Source: Own elaboration 


\section{Empirical methodology}

Our empirical analysis is founded on a survey based on our conceptual model (Figure 2) and conducted on managers in the Italian utilities industry. It may be argued that this model should be analysed through objective indicators taken from a sample including cases of "traditional" governance as counterfactuals. However, at least at present, such an analysis would be too ambitious as public domain information regarding collaborative practices among local actors in infrastructure projects is practically non-existent, and available sources (e.g. press news, sector publications) are unlikely to provide detailed information on actors, objectives and characteristics. At the same time, we are keen to conduct a novel field analysis that explores co-creation from the viewpoint of infrastructure sector managers. We have not found any in-depth investigation of the attitude of firm utilities managers towards multilateral collaboration in available literature, even if firms are normally engaged in public management networks and likely to condition their success or failure.

Despite certain limitations in our empirical approach, the most relevant of which is our reliance upon subjective perceptions, it is important to emphasize the relative advantages of the methodology adopted. Traditional objective indicators can at best reveal to what extent collaborative initiatives have an impact on the implementation of infrastructures, but they do not tell us how this comes about. The importance of disentangling the relations through which collaboration modifies the investment project implies that depth is a necessary dimension of the analysis, as it requires information that is typically beyond publicly available data sources.

\subsection{Sample}

The Italian utilities industry, and more specifically, enterprises offering urban waste, water, wastewater and public transport services, is the test field for our conceptual model and research questions. This industry has been chosen, not only because utility supply services through plants and network infrastructures, but also because the three sectors are widely recognized as suffering from an investment gap. During in-depth exploratory interviews, several experts have stated that a consolidated body of experiences and attempts at collaboration with local actors has been built up. Table 3 illustrates the sample composition with respect to the firm's characteristics.

Potential respondents were identified by consulting the websites of utilities and annual yearbooks compiled by the business association, Confservizi, which represents Italian urban waste and public transport companies. Our questionnaire was then emailed to approximately 500 managers in two rounds. Respondents were identified from board members, chief executive officers, and chief operating officers as these are the people who make the decisions regarding infrastructure development. Assistance was provided by email and phone when required. All in all, 102 questionnaires were returned, but only 99 had been adequately completed (20\% response rate). Large publicly-owned utilities dominate the sample. Moreover, transport enterprises and utilities located in Northern Italy constitute the majority of cases. Our sample is not stratified with respect to the Italian utilities universe (see: Corte dei Conti 2015). Among the questionnaire respondents, larger utilities are overrepresented: the top enterprises (i.e. sales greater than or equal to 50 million Euros) account for $42 \%$ of the sample, while the second class size (i.e. sales of less than 50 million Euros but greater than 10 million Euros) account for 50\% of observations. The geographic location is more aligned to the universe, i.e. environment and local transport utilities located in Southern Italy account for 14\% of the sector.

As far as the respondents are concerned, Table 4 illustrates their individual characteristics. The majority of interviewees are chief executive officers. With regard to education, people with an engineering background are the most relevant group. 
Table 3 - Sample distribution: Enterprise characteristics $(N=99)$

\begin{tabular}{|l|l|c|}
\hline Binary variable & Definition & n. obs. \\
\hline Industry & Water, sewage, urban waste & 43 \\
ENV & Transport & 56 \\
TRAN & Central Italy & \\
Location & Southern Italy & 11 \\
CENTRE & Northern Italy & 14 \\
SOUTH & & 74 \\
NORTH & $10-50$ million Euro & 50 \\
Revenues & More than 50 million Euro & 42 \\
S_10_50 & Less than 10 million Euro & 7 \\
S_50 & & \\
OTHS & $50-149,000$ users & 13 \\
Size & $150-500,000$ users & 55 \\
POP_50_149 & More than 500,000 users & 27 \\
POP_150_499 & Less than 50,000 users & 4 \\
POP_500 & & \\
OTHP & $0-24 \%$ & 6 \\
Public ownership & $25-49 \%$ & 1 \\
PUB_0_24 & $50-99 \%$ & 35 \\
PUB_25_49 & $100 \%$ & 57 \\
PUB_50_99 & & \\
PUB_100 & & \\
\hline
\end{tabular}

Source: Own elaboration

Table 4 - Sample distribution: Manager characteristics $(N=99)$

\begin{tabular}{|l|l|c|}
\hline Binary variable & Definition & Nr \\
\hline Job (not reciprocally exclusive) & Questionnaires \\
PRESB & $\begin{array}{l}\text { president of the board } \\
\text { chief executive officer } \\
\text { CEO }\end{array}$ & 20 \\
COO & other jobs & 58 \\
OTHJ & 5-14 years & 23 \\
Sector experience & more than 15 years & 4 \\
SEXP_5_14 & less than 5 years & 32 \\
SEXP_15 & & 58 \\
OTHSE & degree in law or political science & 9 \\
Education (not reciprocally & degree in engineering \\
exclusive) & degree in business studies or & 13 \\
LAW & economics & 45 \\
ENG & other education & 14 \\
BUS & & 28 \\
OTHED & \\
\hline
\end{tabular}

Source: Own elaboration

\subsection{Questionnaire}

The questionnaire we designed was carefully structured. The first part focused on asking information about "context" variables and possible bias sources, i.e. firm and manager characteristics (Tables 3 and 4) whereas the second part collects qualitative data on the other elements in Figure 2. The questionnaire was validated by means of a number of interviews that have allowed us to improve 
the clarity and consistency of the survey.

Table 5 reports the complete item sets for each of the three key blocks in our conceptual model (Figure 2). The indirect effect of collaboration on infrastructure financing has also been explored. The respondents were asked to express their agreement or disagreement, by selecting answers from a 5-point Likert scale: 1 (strongly disagree), 2 (moderately disagree), 3 (neither agree nor disagree), 4 (moderately agree), 5 (strongly agree). The survey also asks questions about the local actors that should or should not take part in the collaborative initiative; at the same time, it proposes statements that describe the organization of these initiatives. Table 6 reports the complete item sets for the two dimensions.

Table 5 - Benefits and costs of collaborative initiatives: Descriptive statistics $(N=99)$

\begin{tabular}{|c|c|c|c|}
\hline Items & $\begin{array}{l}\text { M } \\
\text { ean }\end{array}$ & $\begin{array}{l}\text { Med } \\
\text { ian }\end{array}$ & $\begin{array}{l}\text { St. } \\
\text { Dev. }\end{array}$ \\
\hline \multicolumn{4}{|l|}{ Knowledge exchange and learning } \\
\hline Project alternatives emerge better if the project is shared & $\begin{array}{l}3.9 \\
6\end{array}$ & 4 & 0.95 \\
\hline Collaboration offers extra important information for feasibility & 3.7 & & \\
\hline analyses and design & 7 & 4 & 0.87 \\
\hline An investment cannot be planned effectively without involving the & 3.6 & & \\
\hline local actors & 9 & 4 & 1.03 \\
\hline Collaboration does help in identifying user requirements and & 3.3 & 4 & 117 \\
\hline problems (reversed) & 8 & 4 & 1.11 \\
\hline $\begin{array}{l}\text { The utility cannot autonomously undertake the high-level investment } \\
\text { (reversed) }\end{array}$ & $\begin{array}{l}2.8 \\
7\end{array}$ & 2 & 1.28 \\
\hline \multicolumn{4}{|l|}{ Time and costs efficiency } \\
\hline Collaboration simplifies the authorisation and permitting process & $\begin{array}{l}3.7 \\
5\end{array}$ & 4 & 1.00 \\
\hline & 3.1 & 4 & 1.25 \\
\hline Collaboration reduces planning times by involving the major actors & 8 & & \\
\hline $\begin{array}{l}\text { Collaboration does improve success chances of investment } \\
\text { realization (reversed) }\end{array}$ & $\begin{array}{l}3.1 \\
1\end{array}$ & 3 & 1.19 \\
\hline $\begin{array}{l}\text { Collaboration is not complex and does not create any additional cost } \\
\text { (reversed) }\end{array}$ & $\begin{array}{l}3.0 \\
7\end{array}$ & 3 & 1.15 \\
\hline \multicolumn{4}{|l|}{ Public acceptance } \\
\hline $\begin{array}{l}\text { Collaboration helps in spreading correct information about facility } \\
\text { characteristics }\end{array}$ & $\begin{array}{l}3.8 \\
6\end{array}$ & 4 & 1.00 \\
\hline $\begin{array}{l}\text { If citizens are involved in the collaboration process through their } \\
\text { representatives, they will have less objections }\end{array}$ & $\begin{array}{l}3.8 \\
2\end{array}$ & 4 & 0.99 \\
\hline $\begin{array}{l}\text { Collaboration is fundamental for identifying compensation, if } \\
\text { necessary }\end{array}$ & 3.7 & 4 & 0.93 \\
\hline $\begin{array}{l}\text { Collaboration does resolve problems related to opposition from } \\
\text { environmental organizations (reversed) }\end{array}$ & $\begin{array}{l}2.9 \\
6\end{array}$ & 3 & 1.18 \\
\hline \multicolumn{4}{|l|}{ Financing } \\
\hline $\begin{array}{l}\text { Resorting to the collaboration system reduces the economic risks of } \\
\text { the project }\end{array}$ & $2^{3.5}$ & 4 & 1.10 \\
\hline $\begin{array}{l}\text { New backers can be identified and attracted through the } \\
\text { collaboration }\end{array}$ & $\begin{array}{l}3.2 \\
2\end{array}$ & 3 & 1.03 \\
\hline $\begin{array}{l}\text { Collaboration facilitates the redefinition of tariff and franchising } \\
\text { conditions }\end{array}$ & 3.2 & 3 & 1.09 \\
\hline Collaboration does simplify relations with backers (reversed) & $\begin{array}{l}3.0 \\
1\end{array}$ & 3 & 1.07 \\
\hline
\end{tabular}

Source: Own elaboration 
As illustrated by Table 5 these statements and their coding were reversed before analysing the sample. Similarly, the order in which the items were presented was random, in order to reduce the common method bias problem. Thirdly, although the survey sample is rather small, the data provides in-depth information about collaboration in infrastructure projects. In particular, the questionnaire, having first provided the respondent with a definition and some examples of collaborative initiatives, then proposed a number of statements regarding three drivers through which collaboration is expected to foster the early stages of infrastructure projects (Figure 2).

Table 6 - Structure and organization of collaborative initiatives: Descriptive statistics $(N=99)$

\begin{tabular}{|c|c|c|c|}
\hline Items & $\begin{array}{l}\text { Me } \\
\text { an }\end{array}$ & $\begin{array}{l}\text { Med } \\
\text { ian }\end{array}$ & $\begin{array}{l}\text { St. } \\
\text { Dev. }\end{array}$ \\
\hline \multicolumn{4}{|l|}{ Structure } \\
\hline Local governments should take part in the collaboration & $\begin{array}{l}4.5 \\
4\end{array}$ & 5 & 0.77 \\
\hline $\begin{array}{l}\text { The presence of local stakeholders encourages investment and } \\
\text { improves level of service performances }\end{array}$ & $\begin{array}{l}3.9 \\
4\end{array}$ & 4 & 0.87 \\
\hline Consumer representatives should be involved in the collaboration & $\begin{array}{l}3.8 \\
0\end{array}$ & 4 & 1.00 \\
\hline $\begin{array}{l}\text { Local environmental associations should be involved in the } \\
\text { collaboration }\end{array}$ & $\begin{array}{l}3.4 \\
4\end{array}$ & 4 & 1.01 \\
\hline Local business associations should be involved in the collaboration & 3.3 & 4 & 1.02 \\
\hline It is wise to limit the number of local governments involved & $\begin{array}{l}3.2 \\
9\end{array}$ & 4 & 1.28 \\
\hline When consumers are involved their input is not very constructive & $\begin{array}{l}2.9 \\
5\end{array}$ & 3 & 1.22 \\
\hline \multicolumn{4}{|l|}{ Organization } \\
\hline Collaboration requires informal meetings & $\begin{array}{l}3.9 \\
1\end{array}$ & 4 & 0.86 \\
\hline $\begin{array}{l}\text { If the length of negotiations is predefined they will be more } \\
\text { successful }\end{array}$ & $\begin{array}{l}3.7 \\
4\end{array}$ & 4 & 0.82 \\
\hline Collaboration leadership should be taken by the utility & 3.4 & 4 & 1.25 \\
\hline $\begin{array}{l}\text { Involving public administration means intensifying red tape } \\
\text { activities }\end{array}$ & 3.2 & 3 & 0.99 \\
\hline "Service committees" are an ideal sphere for the collaboration & 3.2 & 4 & 1.17 \\
\hline Collaboration processes should be given a formal structure & $\begin{array}{l}3.2 \\
6\end{array}$ & 3 & 1.02 \\
\hline $\begin{array}{l}\text { Collaboration should not alter the decision-making process, it } \\
\text { should have a purely advisory capacity }\end{array}$ & $\begin{array}{l}3.2 \\
2\end{array}$ & 3 & 1.22 \\
\hline Collaboration leadership should be taken by local governments & $2^{3.1}$ & 3 & 1.15 \\
\hline $\begin{array}{l}\text { The decision-making process in the collaboration is exposed to } \\
\text { interferences by parties and interests }\end{array}$ & $\begin{array}{l}2.9 \\
0\end{array}$ & 3 & 1.09 \\
\hline
\end{tabular}

Source: Own elaboration

Our survey has some relevant characteristics. First, while we rely on managerial perceptions, we have also checked the competence and expertise of the people interviewed. Managers with considerable experience in the sector (more than 15 years) make up the majority of our observations (58.6\% of the sample, Table 4). Additionally, only 17 out of 99 respondents reported that they had 
not implemented cooperative initiatives with local actors when implementing investment projects. Secondly, certain questions with an opposite meaning have been included in order to strengthen the consistency of the information collected.

\section{Empirical results}

This section describes the empirical evidence obtained from the survey and plots managers' views against our conceptual model by means of simple statistical analyses.

\subsection{Analysis of research questions}

The questionnaire includes a large number of questions relating to the benefits and costs of collaborative approaches for planning, high-level design and siting activities (Table 5). Another group of items represents the network structure and organization (Table 6).

The respondents expressed a general consensus regarding the advantages of collaboration as an institutional arrangement of early project stages. Table 5 reports the sample mean and median for each item. With few exceptions, interviewees agree or strongly agree with all the proposed statements. Questions that were formulated in a negative way, on the contrary, generally received weaker agreement, even though the final reversed coding is rarely "strongly agree". Knowledge exchange and learning and Public acceptance are the conceptual dimensions that attracted the strongest agreement. Managers seem to be more sceptical about Time and cost efficiency and Financing benefits. As to the actors who should be involved in bottom-up initiatives (Structure dimension), the descriptive statistics reported in Table 6 seem to indicate that collaboration strongly requires the participation of local stakeholders, namely local governments and user associations, while the convergence of experts on environmental and business associations is slightly weaker. Among the items that describe Organization, the most shared statements concern the relevance of informal coordination structures with a predefined duration.

In order to learn about our research questions, we have drawn from the survey results the opinions that were expressed with a greater strength or agreement. To this purpose, we have used a one-sample $t$ test of mean differences, which allows us to find out if the mean of answers to a question is statistically higher or lower than the mean of other answers. We have tested if the mean of each item is significantly different from $\mu_{0}$, the cross-item mean (i.e. $\mu_{0}=3.42$ is the sample mean of answers given to all benefits and costs items, Table 7). The null hypothesis is that the difference between the mean of each item and the cross-item mean is zero. Several items are found to have received a mark higher or lower than the general mean (Table 7). The Prevailing agreement column in Table 7 indicates items that receive a stronger than usual agreement ("Yes"), and items that instead are less agreed than other items ("No"). The items where no statistically significant difference emerged have not been reported in Table 7 .

As regards $(\mathrm{Q} 1)$, the interviewed managers are likely to offer a positive answer. More than one item concerning Knowledge creation and transfer show values higher than the general mean at standard significance levels. Early collaboration between public and private actors seems to create conditions for a more effective planning and high-level design of facilities owing to learning-byinteraction processes, i.e. it spurs the acquisition of knowledge critical for selecting design alternatives and analysing the feasibility of infrastructure projects. Utility managers claim that structured interactions between the network participants are especially beneficial to planning activities, while the high-level design activities could be undertaken autonomously by the firm. The idea expressed by the research question on Time and cost efficiency (Q2), on the other hand, is not likely to be accepted by managers. Respondents acknowledge that entering in a network in the early project stages simplifies authorization and permitting procedures, but managers think that additional costs, delays and complexities could emerge from the networks and, as a result, early stage cooperative arrangements do not improve per se the efficiency of infrastructure projects. In contrast to this, the utility managers are likely to answer positively to the last research question, Public acceptance (Q3). More than one item concerning the relationship with residents show significantly high values (i.e. higher than the cross-item mean at standard significance levels; see Table 7). 
More particularly, the concerns of citizens and other stakeholders regarding the technological and environmental characteristics of planned plants evolve when they take part in the process, which also helps in identifying, when needed, appropriate compensations for local "victims". Nevertheless, the opposition expressed by environmental advocacy groups seems to be relatively independent from the governance adopted in early stages. Finally, Financing items received assessments that were not significantly different from the cross-item mean or lower at standard significance levels. In other words, collaboration is regarded as not having indirect positive effects on relationships with financial backers and economic regulation conditions.

Table 7 -Benefits and costs of collaborative initiatives: prevailing views

\begin{tabular}{|c|c|c|c|}
\hline Items & $\begin{array}{c}\text { Mean } \\
\text { difference }^{\wedge}\end{array}$ & $\begin{array}{c}\mathrm{p}- \\
\text { value }^{\circ}\end{array}$ & $\begin{array}{l}\text { Prevailin } \\
\mathrm{g} \\
\text { agreement\# }\end{array}$ \\
\hline \multirow{5}{*}{$\begin{array}{l}\text { Knowledge exchange and learning } \\
\text { Project alternatives emerge better if the project is } \\
\text { shared } \\
\text { Collaboration offers extra important information for } \\
\text { feasibility analyses and design } \\
\text { An investment cannot be planned effectively without } \\
\text { involving the local actors } \\
\text { The utility cannot autonomously undertake the high- } \\
\text { level design }\end{array}$} & & & \\
\hline & 0.54 & $* * *$ & Yes \\
\hline & 0.35 & $* * *$ & Yes \\
\hline & 0.27 & $* *$ & Yes \\
\hline & -0.55 & $* * *$ & No \\
\hline \multirow{5}{*}{$\begin{array}{l}\text { Time and cost efficiency } \\
\text { Collaboration simplifies the authorisation and } \\
\text { permitting process } \\
\text { Collaboration reduces planning times by involving } \\
\text { the major actors } \\
\text { Collaboration does improve success chances of } \\
\text { investment realization } \\
\text { Collaboration is not complex and does not create any } \\
\text { additional cost }\end{array}$} & & & \\
\hline & 0.33 & $* * *$ & Yes \\
\hline & -0.24 & $*$ & No \\
\hline & -0.31 & $* *$ & No \\
\hline & -0.35 & $* * *$ & No \\
\hline \multicolumn{4}{|l|}{ Public acceptance } \\
\hline $\begin{array}{l}\text { Collaboration helps in spreading correct information } \\
\text { about facility characteristics }\end{array}$ & 0.44 & $* * *$ & Yes \\
\hline $\begin{array}{l}\text { If citizens are involved in the collaboration through } \\
\text { their representatives, they will have less objections }\end{array}$ & 0.40 & $* * *$ & Yes \\
\hline $\begin{array}{l}\text { Collaboration is fundamental for identifying } \\
\text { compensation, if necessary }\end{array}$ & 0.28 & $* * *$ & No \\
\hline $\begin{array}{l}\text { Collaboration does resolve problems related to the } \\
\text { opposition from environmental organizations }\end{array}$ & -0.46 & $* * *$ & No \\
\hline \multicolumn{4}{|l|}{ Financing } \\
\hline $\begin{array}{l}\text { New backers can be identified and attracted through } \\
\text { the collaboration }\end{array}$ & -0.20 & $*$ & No \\
\hline $\begin{array}{l}\text { Collaboration facilitates the redefinition of tariff and } \\
\text { franchising conditions }\end{array}$ & -0.20 & $*$ & No \\
\hline Collaboration simplified relations with backers & -0.41 & $* * *$ & No \\
\hline
\end{tabular}

Source: Own elaboration

Notes: one sample t-test $\left(\mathrm{H}_{0}: \mu_{\text {item }}=\mu_{0}\right)$ : test on the difference between the mean of each item $\left(\mu_{i}\right)$ and the general mean of the items concerning benefits and costs $\left(3.42, \mu_{0}\right)$; ); \#, Ho rejected: Yes $=\mu_{\text {item }}>\mu_{0}$, No $=\mu_{\text {item }}<\mu_{0} ;{ }^{\circ}: * \mathrm{p}<.10 ; * * \mathrm{p}<.05 ; * * * \mathrm{p}<.01$.

\subsection{Structure and organization of cooperative initiatives}


The interviewees were also asked to indicate which structures and organizations are more appropriate for cooperative agreements (Table 6). The dominant opinions on this matter can be described very synthetically as the outcome of the one-sample $t$ tests (Table 8). As far as the Structure of collaborative initiatives is concerned, experts emphasize the opportunity to involve local stakeholders, namely local governments and consumer representatives (i.e. agreements greater than the cross-item mean, at standard significance level). Consumers are reckoned to play a constructive role. Managers have a well-defined attitude towards the functioning mechanisms of early stage collaborative arrangements (Organization). In order to be successful, networks should have a predefined duration and involve informal interaction between the participants, but managers do not accept the leadership of local governments and believe that collaboration should alter the decision making process, i.e. it should have more than a mere advisory function. Relative scepticism is expressed about the chance of external pressure on the network.

Table 8 - Structure and organization: prevailing views

\begin{tabular}{|c|c|c|c|}
\hline Items & $\begin{array}{c}\text { Mean } \\
\text { difference }\end{array}$ & $\begin{array}{l}\text { p- } \\
\text { value }^{\circ}\end{array}$ & $\begin{array}{l}\text { Prevailin } \\
\quad \mathrm{g} \\
\text { agreement } \\
\quad \#\end{array}$ \\
\hline \multirow{4}{*}{$\begin{array}{l}\text { Structure } \\
\text { Local governments should take part in the } \\
\text { collaboration } \\
\text { Consumer representatives should be involved in the } \\
\text { collaboration } \\
\text { When consumers are involved their input is not very } \\
\text { constructive }\end{array}$} & & & \\
\hline & 1.08 & $* * *$ & Yes \\
\hline & 0.34 & $* * *$ & Yes \\
\hline & -0.51 & $* * *$ & No \\
\hline \\
\hline $\begin{array}{l}\text { If the length of negotiations is predefined they will } \\
\text { be more successful }\end{array}$ & 0.28 & $* * *$ & Yes \\
\hline Collaboration require informal meetings & 0.45 & $* * *$ & Yes \\
\hline $\begin{array}{l}\text { Involving public administration means intensifying } \\
\text { red tape activities }\end{array}$ & -0.17 & $*$ & No \\
\hline $\begin{array}{l}\text { Collaboration processes should be given a formal } \\
\text { structure }\end{array}$ & -0.20 & $*$ & No \\
\hline $\begin{array}{l}\text { Collaboration should not alter the decision-making } \\
\text { process, it should have a purely advisory capacity }\end{array}$ & -0.24 & * & No \\
\hline $\begin{array}{l}\text { Collaboration leadership should be taken by local } \\
\text { governments }\end{array}$ & -0.34 & $* * *$ & No \\
\hline $\begin{array}{l}\text { The decision-making process in a cooperative } \\
\text { initiative is exposed to interference by parties and } \\
\text { interests }\end{array}$ & -0.56 & $* * *$ & No \\
\hline
\end{tabular}

Source: Own elaboration

Notes. ${ }^{\wedge}$, one sample t-test $\left(\mathrm{H}_{0}: \mu_{\text {item }}=\mu_{0}\right)$ : test on the difference between the mean of each item $\left(\mu_{i}\right)$ and the general mean of the items concerning the network structure and organization $\left(3.46, \mu_{0}\right)$; $\#, \mathrm{H}_{0}$ rejected: Yes $=\mu_{\text {item }}>\mu_{0}, \mathrm{No}=\mu_{\text {item }}<\mu_{0} ;{ }^{\circ}: * \mathrm{p}<.10 ; * * \mathrm{p}<.05 ; * * * \mathrm{p}<.01$.

\subsection{The role of external factors}

An additional analysis has been conducted to investigate whether the managers' answers were sensitive to the context and experience of the respondents. A two-sample $t$ test of mean differences has allowed us to explore the existence of antecedents. In particular, we have statistically investigated if the attitude of managers towards the networks varies with the firm's size, ownership and sector. 
For the sake of brevity, here we only comment on the empirical evidence corroborated by tests at standard significance levels. The statistical results are available upon request from the authors. Managers from larger utilities are more sceptical about the role of collaboration in smoothing possible problems related to environmental advocacy opponents, while they consider early stage collaboration as a catalyst for the authorisation and permitting process. No significant evidence has emerged with respect to utility ownership. By contrast, a clear difference emerges between utilities that provide environmental services and enterprises in the transport sector. A relatively stronger consensus on our three research questions characterizes the environmental utilities, while the local public transport managers seem to suffer from greater scepticism.

Finally, we have tested whether opinions differ significantly between managers with greater and lesser experience in the sector. The managers' expertise does not seem to be at odds with reliance on the networks, especially when the learning-by-interaction process and public acceptance issues are considered.

\section{Discussion of results and conclusions}

Policy-makers and experts converge to recognize that an infrastructure gap is emerging in advanced countries, due to multiple failures in planning, design and siting activities. A growing body of studies seeks solutions in collaborative arrangements between multiple stakeholders. In order to analyse how and to what extent this collaborative approach may foster the development of urban infrastructures, a survey has been conducted on a sample of managers that operate in the local transport, water and sewage, and urban waste management sectors. We focused on the early stage of project development.

Respondents confirm that collaborative behaviour in early project stages generates positive results. Greater benefits are obtained in the Knowledge and Public Acceptance domains. The access to tacit and specific pieces of knowledge about alternative project options and investment feasibility is highly considered by managers. Learning-by-interaction is a major strength point of cooperative approaches to infrastructure projects. The stakeholders' engagement has been found by interviewees to reduce possible conflicts with residents. The divergence of expectations is managed by sharing information regarding the technological and environmental characteristics of the planned facilities, which creates a basis for support (see also Beach et al. 2012 and Glasbergen and Driessen 2005). Nevertheless, it cannot be excluded that these positive effects are traded off against a lack of progress in the area of Efficiency. The permitting procedures that frequently create a time escalation in infrastructure projects are effectively managed when early stages are governed through a collaboration (Glasbergen and Driessen 2005), but other inefficiency sources do not find a remedy with the cooperative governance approach.

Despite the preliminary character of this analysis and its limits, it still offers a number of managerial and policy implications for the sector.

Firstly, special attention should be paid to the in-depth knowledge of site-specific characteristics, community needs and expectations, problems and potential contributions from the entire set of stakeholders. This has often been taken for granted by utility management, determining the problem of infrastructure inadequacy with respect to the destination community and territory, and encouraging the Nimby syndrome. Secondly, the participation of local governments, utilities and other local stakeholders in cooperative interaction is essential in the very early stages of infrastructure projects, namely in planning, siting and high-level design activities. Finally, a major channel through which public acceptance of infrastructure investments is enhanced is the exchange of information regarding the environment and health implications of the project.

In the future, this research may be developed by extending the empirical analysis to local governments and non-governmental associations. The reasons why collaborative arrangements in early project stages are considered inefficient, or not more efficient than traditional governance, is 
another area worth investigating. Finally, further efforts should be made to analyse the flows of tangible and intangible resources within the early stage collaboration, in order to find out what relationships are more likely to suffer from transaction costs, and to reflect on possible remedies.

\section{Bibliographical references}

Beach, S., Keast, R. and Pickernell, D. (2012) Unpacking the Connections between Network and Stakeholder Management and their Application to Road Infrastructure Networks in Queensland Public Management Review, 14:5, 609-629

Cooper, T., Bryer, T. and Meek, J. (2006) Citizen-Centered Collaborative Public Management Public Administration Review, 66 (special issue), 76-88.

Corte dei Conti. 2015. Gli Organismi partecipati degli enti territoriali. Roma: Corte dei conti Sezione delle Autonomie.

Cotton, M. and Devine-Wright, P. (2011) Discourses of energy infrastructure development: a Qmethod study of electricity transmission line siting in the UK Environment and Planning A, 43(4), 942-960.

Dürrenberger, G., Kastenholz, H. and Behringer J. (1999) Integrated assessment focus groups: bridging the gap between science and policy? Science and Public Policy, 26 (5), 341-349.

Ennis, F. (2003) Infrastructure Provision and the Urban Environment. Edited by Frank Ennis, Infrastructure provision and the negotiating process: 39-55.

Fischer, F. (1999) Technological deliberation in a democratic society: the case for participatory inquiry Science and Public Policy, 26 (5), 294-302.

Flyvbjerg, B., Holm, M.S. and Buhl, S. (2002) Underestimating Costs in Public Works Projects: Error or Lie? Journal of the American Planning Association, 68(3), 279-295.

Flyvbjerg, B. (2009) Survival of the unfittest: why the worst infrastructure gets built and what we can do about it Oxford Review of Economic Policy, 25(3), 344-367.

Furlong C., De Silva S., Guthrie L., and Robert Considine (2016) Developing a water infrastructure planning framework for the complex modern planning environment, Utilities Policy, $38,1-10$.

Garrone, P. and Groppi, A. (2012) Siting energy facilities: What can be learnt from the location of Italian power plants? Energy Policy, 45, 176-186.

Glasbergen, P. and Driessen, P.J. (2005) Interactive planning of infrastructure: the changing role of Dutch project management Environment and planning C: Government and Policy 23(2): 263-77.

Gnan L, Hinna A., Monteduro F. and Scarozza D. (2013) Corporate governance and management practices: Stakeholder involvement, quality and sustainability tools adoption, Journal of Management and Governance, 17: 907-337.

Golinelli G.M. (2000) L'approccio sistemico al governo dell'impresa, Cedam.

Governa, F., and Salone, C. (2005) Italy and European Spatial Policies: Polycentrism, Urban Networks and Local Innovation Practices European Planning Studies, 13 (2), 265-283.

Groves, C., Munday, M. and Yakovleva, N. (2013) Fighting the pipe: neoliberal governance and barriers to effective community participation in energy infrastructure planning Environment and Planning C: Government and Policy, 31:340-356.

Hefetz, A. and Warner, M.E. (2007) Beyond the market versus planning dichotomy: Understanding privatisation and its reverse in US cities Local Government Studies, 33:555-72.

Heikkila, T., and Gerlak, A. K. (2014). Investigating Collaborative Processes Over Time A 10Year Study of the South Florida Ecosystem Restoration Task Force. The American Review of Public Administration.

Hillier, J. (2000) Going round the back? Complex networks and informal action in local planning process Environment and Planning A, 32(1), 33-54.

Hodge, G.A. and Greve, C. (2007) Public-Private Partnerships: An International Performance Review Public Administration Review, 67:545-58.

Hörning, G. (1999) Citizens' panels as a form of deliberative technology assessment Science and 
Public Policy, 26 (5), 351-359.

Jaakkola E. and Hakanen T. (2013) Value co-creation in solution network, Industrial Marketing Management, 42: 47-58.

Keast R. and Mandell M. (2014) The collaborative push: moving beyond rhetoric and gaining evidence, Journal of Management and Governance, 18: 9-28.

Koppenjan, J.F.M. (2005) The formation of public-private partnership: lessons from nine transport projects in the Netherlands Public Administration, 83(1), 135-157.

Kwak, Y. H., Chih, Y. Y. and Ibbs, C. W. (2009) Toward a Comprehensive Understanding of Public Private Partnership for Infrastructure Development California Management Review, 51(2):5176.

Marvin, S. and Guy, S. (1997) Infrastructure Provision, Development Processes and the Coproduction of Environmental Value Urban Studies, 34(12), 2023-2036.

Mele C. (2011) Conflicts and value co-creation in project networks, Industrial Marketing Management, 40: 1377-1385.

Miglietta A. (2005) La nozione di creazione di valore nelle imprese locali di servizi pubblici, in Dezi L., Gilardoni A., Miglietta A., Testa F., Economia e Management delle imprese di pubblica utilità, Cedam.

Nooteboom, B. (2000) Learning by Interaction: Absorptive Capacity, Cognitive Distance and Governance Journal of Management and Governance, 4:69-92.

Organisation for Economic Co-operation and Development (2006) A cross-sectoral perspective on the development of global infrastructures to 2030. Infrastructure to 2030 - Volume 1. Telecom, Land Transport, Water and Electricity. Paris: Organisation for Economic Co-operation and Development.

Organisation for Economic Co-operation and Development (2007) Infrastructure to 2030: Main Findings and Policy Recommendations. Infrastructure to 2030 - Volume 2: Mapping Policy for Electricity, Water and Transport. Paris: Organisation for Economic Co-operation and Development.

Ostrom, E., Schroeder, L. and Wynne, S. (1993) Institutional Incentives and Sustainable Development. Infrastructure Policies in Perspective, Boulder Westview Press.

Provan, K.G., and Kenis, P. (2008) Modes of network governance: Structure, management, and effectiveness Journal of Public Administration Research and Theory, 18: 229-52.

Ranjan, K.R. and Read, S. J. (2016) Value co-creation: concept and measurement, Journal of the Academy of Marketing Science, 44: 290.

Schweizer P. and Bovet J. (2016) The potential of public participation to facilitate infrastructure decision-making: Lessons from the German and European legal planning system for electricity grid expansion, Utilities Policy, in press.

Sclove, R. (2000) Town Meetings on Technology. Consensus Conferences as Democratic Participation. In Kleinman (2000), 33-48.

Walker, G. and Devine-Wright, P. (2008) Community renewable energy: What should it mean? Energy Policy, 36 (2), 497-500.

Watson, J. (2004) Co-provision in sustainable energy systems: the case of micro-generation Energy Policy, 32 (17), 1981-1990.

Wiewiora, A., Keast, R., \& Brown, K. (2016) Opportunities and challenges in engaging citizens in the co-production of infrastructure-based public services in Australia. Public Management Review, 18(4), 483-507. 